理と古家本態土こは過 2 た合農

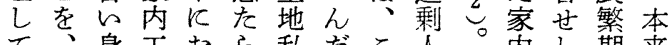
て、身和ら私だこ人。内し期来 はい分業いし有まの口てエめに

なわ的をてめ制まてをの業て対家

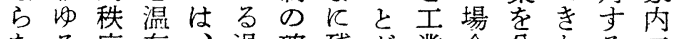
なる序存、過確残が業合分たる工 い封をせ農小立さそに、離の農業 建残ざ業農は独の吸農しで閉は 明性存る加経、七収業、あ期農 治でせをら営農りましか、るるは業 政あざ得工を村る。実てられ。必充 府るるな業普の。現ら工资然密 のとをかを及過即せか業自本的接 土か得つ完せ剩ちずね老主に不 地前なた全し人、、ば分の義な可 私近加事质め口明農な離確はん分 有代つ情分てを治村ら寸立、らに 化性たが離をし六は好る立こか結 にでのあでたて年異のと基ののび よあでりきの常の常でと盤よ手つ るるあ、ずでに地なあに㭰5エい 近々るま、文産租過るよと学て 代か。農る業改剩がうし農的い 的のし、業 予正学、てて業生た 土理かとの 3 備飞働 日生発と産\& 地解しのな。軍よ力本す展結をの 所と、とかてのるをにるし合農で 有してとにと特近かお農てし業あ

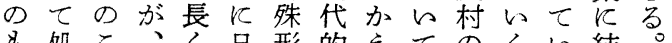
\&処と、く日形的元てのく結。

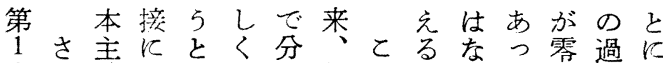
表七義問すは離伝の方細剩形 で、の 5 る結し統論でて、農人成 敃基\& \& 合て 的稿あ、零経口さ らこ盤のの年ににる特細営のれ れでをでで契た農お。殊農を問た る特問はあ機か業い経形題地 よ題なるを、とて 日営成が主 5 漆にく。家若結は本反儿生的 K、器し、そ内し合、のま、じ士

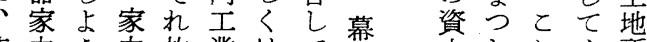
漆内 5 内故業はて幕本われく所 器工と工、地結いか主るにる有 工業す業こ域びたら義身よのが 業地る地このつ家の架分つで過 は域名域で支い内瓷生的てあ小 明をののは配て工資文秩資る農 治調で事日体的業本出序本。経 以查む例本制る染主美出主即営 前地る研資をか、義登封義ち究 かと。究本中、農発近建㤎、生 らし主心そ業過代性確日生

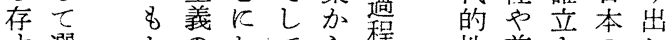

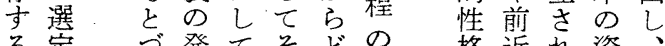

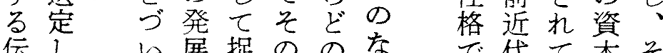
伝しい展捉ののな代て本そ 統たて過公分占市性的主こ 的の日程て離 5 でるなる義に 国は本を的落落のの自農 内、資直こ若形徒的でで身村

県

雄 お

勝り け

郡 る

川支支

地莗? 配

区体

1 制

の

場变 合動

佳

藤 
苐 1 表 漆器主要産地別企業の歷史

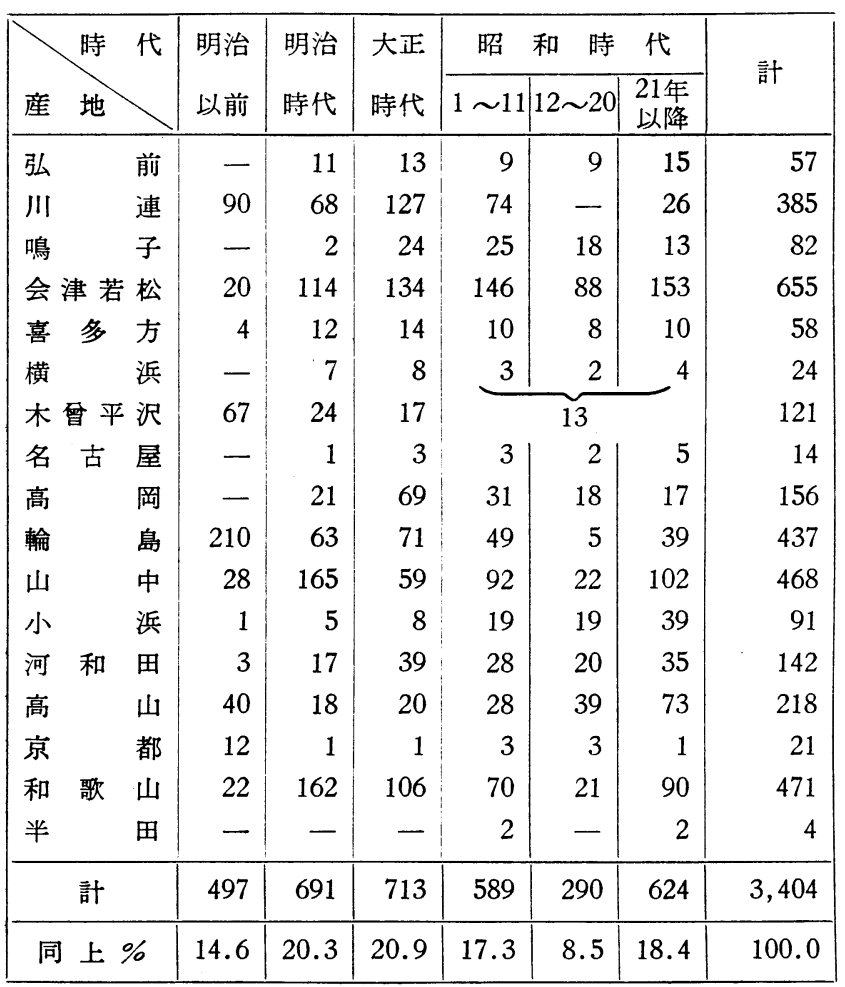

握的た特産

でにに業

をと川で

る拘連あ

とょら地 り

ケです、注そ

理、い他の

由農まの殆

に業だ産ど

上と農地が

る漆業が農

8 器 兼 既 業

の工業にと

で業と早の

あとしく連 るのてか関

。結のらに

更合漆漆市

反お器器々

ᄀ王工

支び業業捉

配分古尃

体離ら業ら

制形脱化れ

し態しをる

はをき完と

容つ成と

乙易て

と

（総理府赫計局調查による。昭和 29 年度調查）

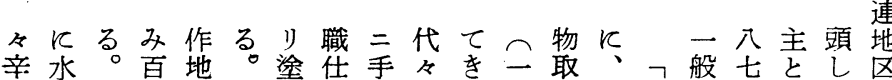

苦吞と姓がこ物候職一た公扱曾高的 ○して

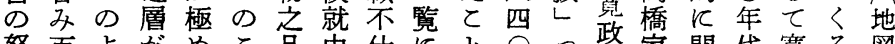

努百よがめと品中仕飞と $と っ$ 政家問代寛る図

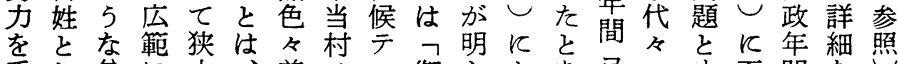

重し貧に少、差人八御らかす寻一寸至間な

ねて農停でて出内御百かけりり覧るるへプに

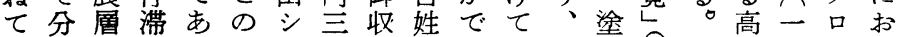

漸家かしり地如拾納下古高文物 7 橋七七け

くしらてへ域何軒二八る橋政ノし

寛た、ら第庄様隣相乍。家へ投に

政初享た 2 他三村難申更が一資よ

年代保こ表のモ大候一体入産れ

代利年々参近取館三体弘格二業ば

の兵間を照隣続村テ御化的 $\overline{0}$,

四衛 $\frown$ 物、地キ六村田四に祭四

代以二語的域罷拾方地年塗か発代

六後主るわ在軒三不乞物ら

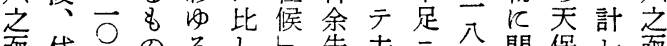

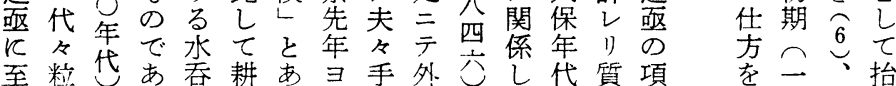

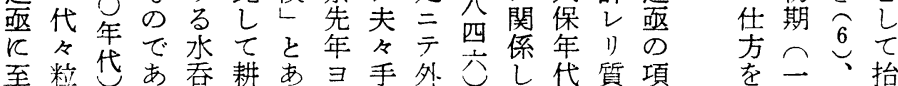

家九杂る

漆年つ橋

器代 家

工業が が

のら一方

把明切商

握治省人

の初きと

方 $气 \underset{\text { 期 }}{\widehat{6}}$ 导

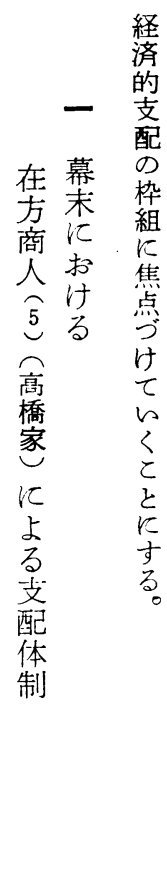



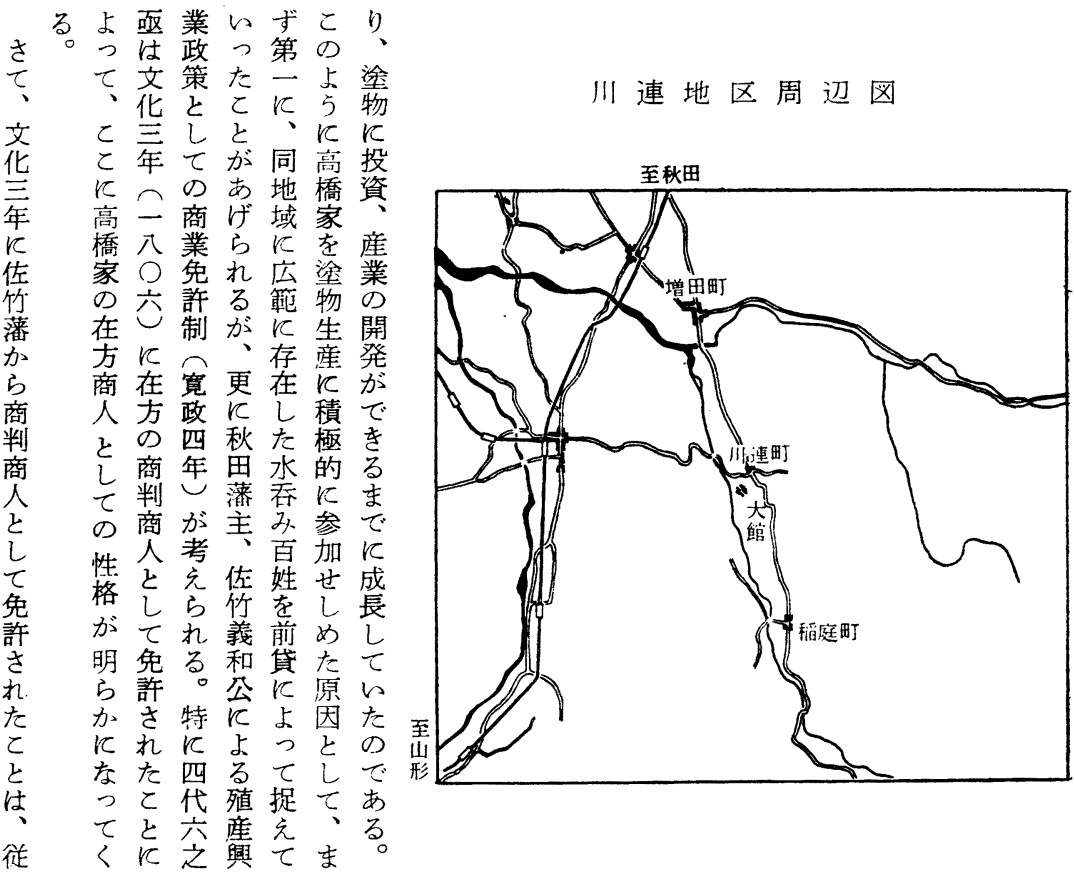

第 2 歨 耕 作 地 面積比較

\begin{tabular}{|c|c|c|c|c|c|c|c|c|c|}
\hline \multirow{2}{*}{ 町 } & \multirow{2}{*}{ 村 } & \multirow{2}{*}{ 名 } & \multirow{2}{*}{ 戸 } & \multirow{2}{*}{ 人 口 } & 耕 & 作 & 地 & \multirow{2}{*}{ 山 林 } & \multirow{2}{*}{ 原 野 } \\
\hline & & & & & 田 & 畑 & 計 & & \\
\hline 川 & 連 & 村 & 509 & 3,702 & $\begin{array}{c}\text { 町 反 } \\
197.6\end{array}$ & $\begin{array}{l}\text { 町 反 } \\
89.3\end{array}$ & $\begin{array}{c}\text { 町 反 } \\
286.9\end{array}$ & $\begin{array}{l}\text { 町 反 } \\
85.3\end{array}$ & $\begin{array}{l}\text { 町 反 } \\
78.9\end{array}$ \\
\hline 駒 & 形 & 村 & 478 & 3,659 & 445.0 & 128.1 & 573.1 & 275.0 & 620.4 \\
\hline 三 & 梨 & 村 & 383 & 2,920 & 290.8 & 161.1 & 451.9 & 198.6 & 484.1 \\
\hline 稻 & 庭 & 町 & 363 & 2,520 & 138.5 & 153.1 & 291.6 & 166.6 & 220.3 \\
\hline
\end{tabular}

大正 5 年 12 月末現在。秋田県雄勝郡较計要臨（大正6年7月）より。

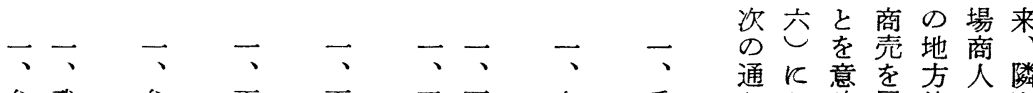

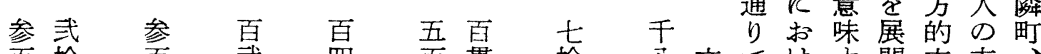
百拾香武四百貫拾公齐でけ卞開市支 四五吾拾拾七文公拾政あるるし場配増 拾貫拾公売拾貫参九る同。得の思 武六貫貫貫四絵五貫戍丙。家文る5

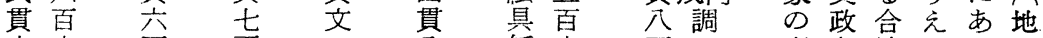
文文面百分紙文百店九法飞っ目

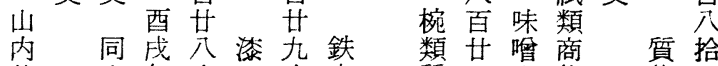

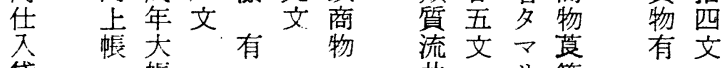
镸 共少等 調年性、た参 的索川照 上一得橋連 る公た家近の と三とが在市 
生々高費的る品る豆物原業

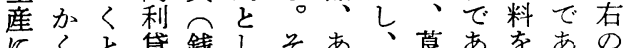

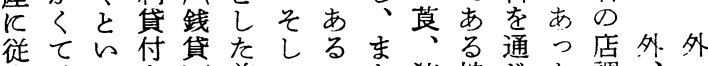

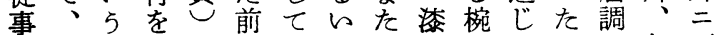

す文よ意だ貸とは紙汁類てとに年百

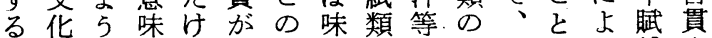

よ去しで行段嘫集川监る銭文

5 文性、なわ階等木集積連明と

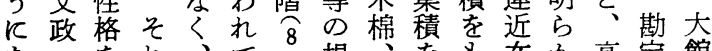

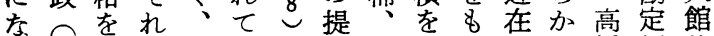

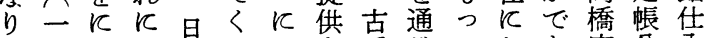

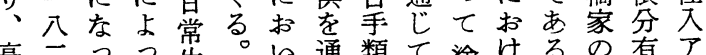

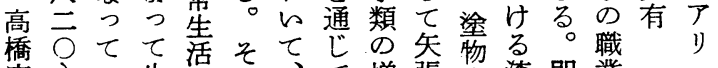

家々b生必れ、堌張生漆即業

の至た産需は農近田员産物ち形

経 $\mathrm{O}$ 者品単民在商近痤生、態

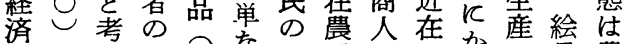

的以公全物学生民を加筫農

支後ら生貸生産の介商わ関赤業

配势産貝生物商し品わ係赤

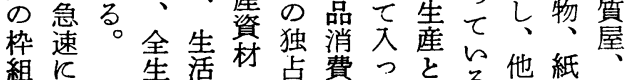

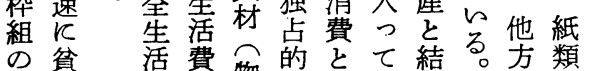

の贫活費物的とて結る。方類商

な農支銭貸占會る結くび更そ漆の

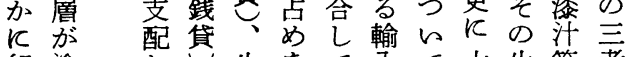

組染しし生をて入て大生等者

み物ての産目的商い小産の兼

内参五七武六五

正拾拾面拾百

五百面貣宍貫貫

貫参文文貫壱六

文 拾

参百百交

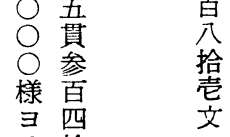

参預吉

百

参

拾

$\begin{array}{lll}\text { 参 } & \text { 年 } & \\ \text { 百 } & \text { 季 } & \\ \text { 西合 } & \text { 金 } \\ \text { 七 } & \text { 尚 } & \text { 作 } \\ & \text { 粐 }\end{array}$

大年万万四

小賦 勘 当百

豆帳定坐 拾

有炎帳帳公

は倍るる る 入

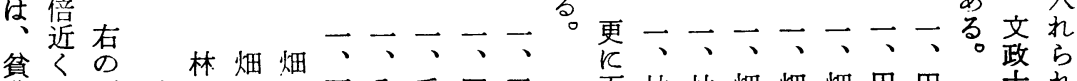

農飞不林畑畑百八千四五关林梱畑畑田田政占

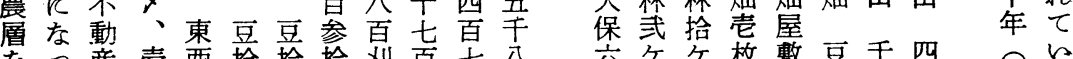

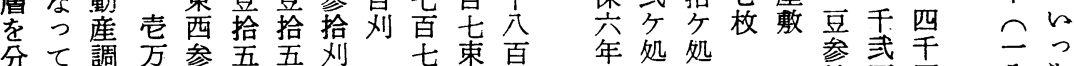

て調万参五五㺫吉束百

しる。占百尔打打

器高拿苯

人家政

椀塗年

飯当畠小三大鄉正

公

参面四

家物 加

田村等安梨 館 内

の

業生彦

師産瓦

化対文

せす年

己る 間

め前 $\sqrt{ }$

、貸田

そ 的 畑

の 買山

結占林

果的

資在

貧本 将

不

不

摌

k

る 叴等总当

俵则百 三の

打

四 七で

次政々安臀々館々

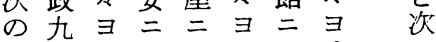

よ年り テ テリテリの

5 持持持持持持持 如

范分分分分分分分交 
にの免三

上法許年以 つ的江上 て支更打の 完柱飞外概 成を末る括 さ背座在 $几$ れ景御方 \& た懸商明 とし晳判 ら 的飞商名 5 同し人な 乙地てのよ 域在免 5 がの株許に で貧を

農構文高 る層成政橋 るをす十家 第半る三の

1 農と年 経 図半的乞済 参工 5 - 的 照によ八支 変 5 二配 質飞九体

初さ制

農せ幕のは、

層る藩質

椀と制の化
る座易輸四に て水年と経はに 営四保農 御し入年対と彼漆、絵黨じ至高さ\%+層 懸の禁へしの自己古具をめる橋れ、三か 所故止一七占身絵手の質、。家る貧年ら とを令八、5慎、直的更即は家農現田 し以上四天な天と繰接 $\nwarrow \nwarrow ち$ 六内層在畑 てっに七保高保の綿取転士、代工七の山 朱てょし十橋 七交の引換三天利業三川林 一そるの三家年易輸をさ年保兵と\%連を 手れ虰増年の肝等入しせ加艺衛しで村驱 販ら方田、先煎、、、七ら年のて、に奪

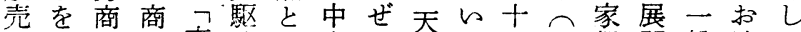
の突人人市的な央ん保く五一督開般けて 特破のの場なる市ま五。年八相しにるい 権し压压以場的年まの三続て二整っ を、泊迫曻問吕、以た間九をい、物た 得遂を商尾直絹降文几し契っ三生と

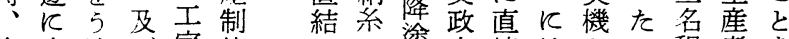
在安けで家的との整士接はとの程者を 株政な安業ない輸物三塗、しで度は物 を六が政禁い 5 出の年物染てあのの語 構年ら年止し形と去へ生屋一る家富っ

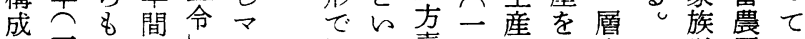
す公ののが二展5売八を労層い

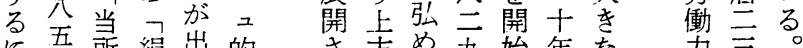

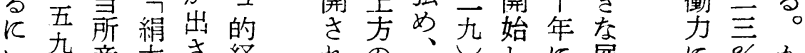

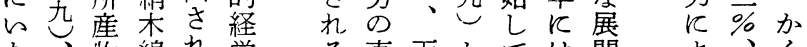
た、物綿れ営方直天かて保開占中く

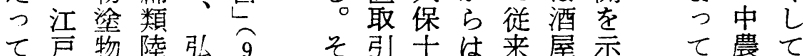
的朱交路化しし三京のを者層天
経支配て幕

生し畕高末

活七農橋机

のいか家挑

全つらの

領た背在て

域高負方背

を橋小商 負

支家商人小

配のへと商

寸存々 L, K

る在上七 対

もは算のす

の、し.生る

と盆、長增

し農更が田

て $\mid$ 攵商

位椀川ら人

置稼連れの

し業地た支

乙師域。配

いかのと統

たら畕の制

のみ農よの

でれ層 58

あばをなと

る、経関に

自済係

例已的飞は

えのに抏じ
的多たいゔ

的角とてけ

拈的衫

二小経え衣れ

ず営るして

明台㥞式とそた

限多のと

界生と即

が文とまち

お横出吕度、高橋家

るわれ高橋器

五った橋家業

てし家の

い、の在農

た反農方閉

支で面商人業

あ の织々

る経去しし

的三の農

支者支業貧立身師るで藩\&し橋即稼 配兼配と農でとは。\&体あて家ち業 の業\&密層をしとしあ制りのの脱師 籁に可接とずてとかつの、上在農へ

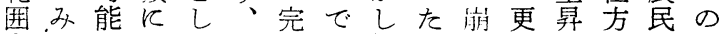
母らで結てい全そ椀の壞反過商化転 地れあび位ま机稼で過は程人化 域るつつ置だ独自業あ程幕でと高 
さにナ参恐貫千参払記して橋新次生田か高生死 ば れ8以拾敷之五百之フして、家を第産商つ橋産佶同

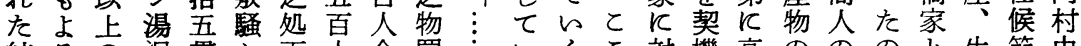
結るの沢貫 嗄人余買 $\vdots \backsim く と$ 対機高のののと生節中 果と文三之ク貫モ諸多正る。秋と橋流支で出活○久 でと面テ胄ナ三出方人月䯩椀るす家通配あ入資銭保 あなと参り相候寻数中 るがあ店公夕成噂り二米

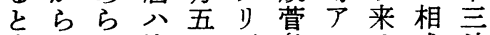
考、わ皆百正系りり成斗 完維れ $邓$ 札百当当諸入 ら新た切一参多地㙦方壱 れを事休円拾二叙物寻俵 る契情業通日付物分り参 。機は角湯金公拾買拾 とと幕ナナ沢四壱貫人七 のし策ルシへ両揃寻入貫 乙てか：両地增七り込文 とイら 替図葉拾七候此 $K ン$ 明 $\leftarrow$ 七参煙貫拾事時 よフ治へ拾照草之吾恐妇 つレ初括貫し百処貫敷り 一 I期弧米二质百二当両 高シの内公テ参武相沢替 橋 3 貨筆何米百拾成合 家 $ン$ 幣者程五吾貫横川高 はの制註三拾拾米手連值 明波度しテ参貫参二地二 治灯の毛貫拾買区相 宍さ亲売蚺相㫐物 成 橋稼商るの形加る関金兰 家業業制支態ら。係号貫善 代師兔度配が脱そを文兵 々は許的か背却し \&文 一公変ら負してつと 覧然江革抜小七ここ市藍日 反局にけ商いのと場に記 よ高朱よ出でくょにと而帳 る橋座ってあと 5 よ直勘 と家御ているとなっ結定天 明の懸、くこが収てし仕保 治支所各機とで奪徾得 ○十 至配 の藩会にをの底る三三 年の機のをよた強し程而年 正網能領\&うの行たの借年 月絮域つてでを収深うに のら消のて、あ通奪さ 模脱失封に臀つじををしる

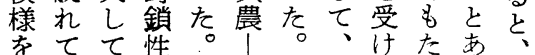
次背い性特し椀し高ざ好るフ の負く破飞稼加橋る畕よ親 上行飞明業し家を農 5 父 5 商つ、治師漆は得層飞○ 飞化れ高維は器増なが、病

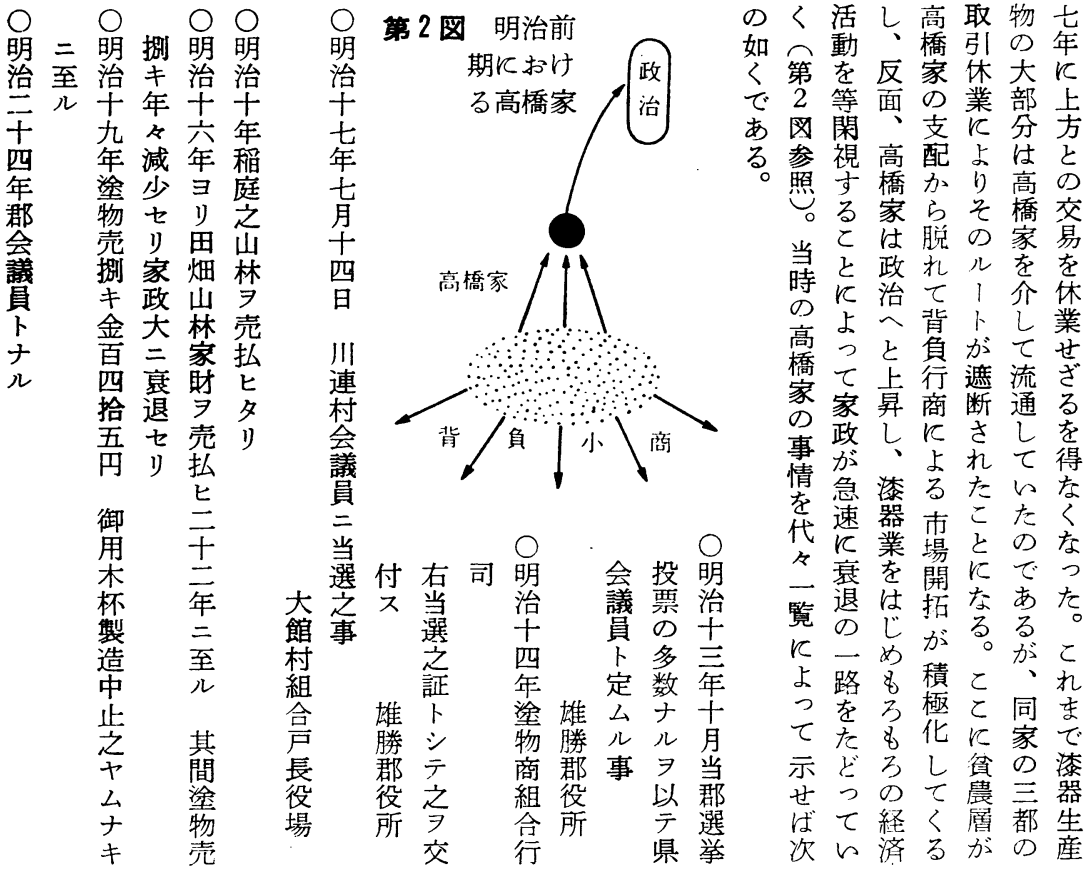


の盉 5 緎露換

造業な維のを資明

出及新王両基本治 をびし 業戦盤の原云 結諸々 後に原十 果副工重業転て的代

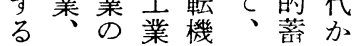
。永発部と的霣 ら

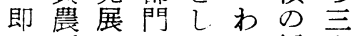
ち層はがてゆ槓十 、の、飛アる杆年 自出一躍涪産と代 作稼方的力業しに 中江长資た 農身打発示本官外 が売い展计の賞て 自等てをる時諸は 作を農は市期工、 地通村じ場で場明 主じのめ及あの治 化て中てびつ近六

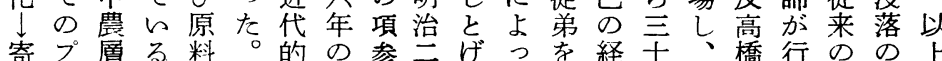
生口を。供そ生地照干てて㔔営年明家商貧間の 地し中し給し産租年的漆加の代治勢化農隐よ。 主夕核かがて様改 化りとし確旦式正 分卞と保清命を

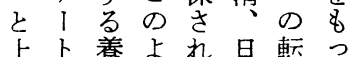

第 3 表 年期徒弟数の変動

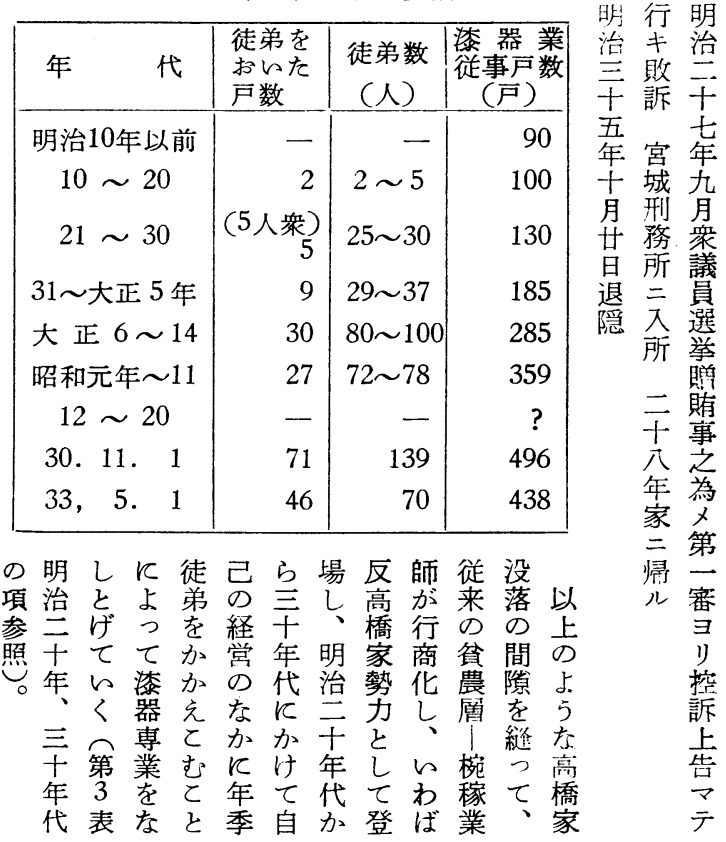

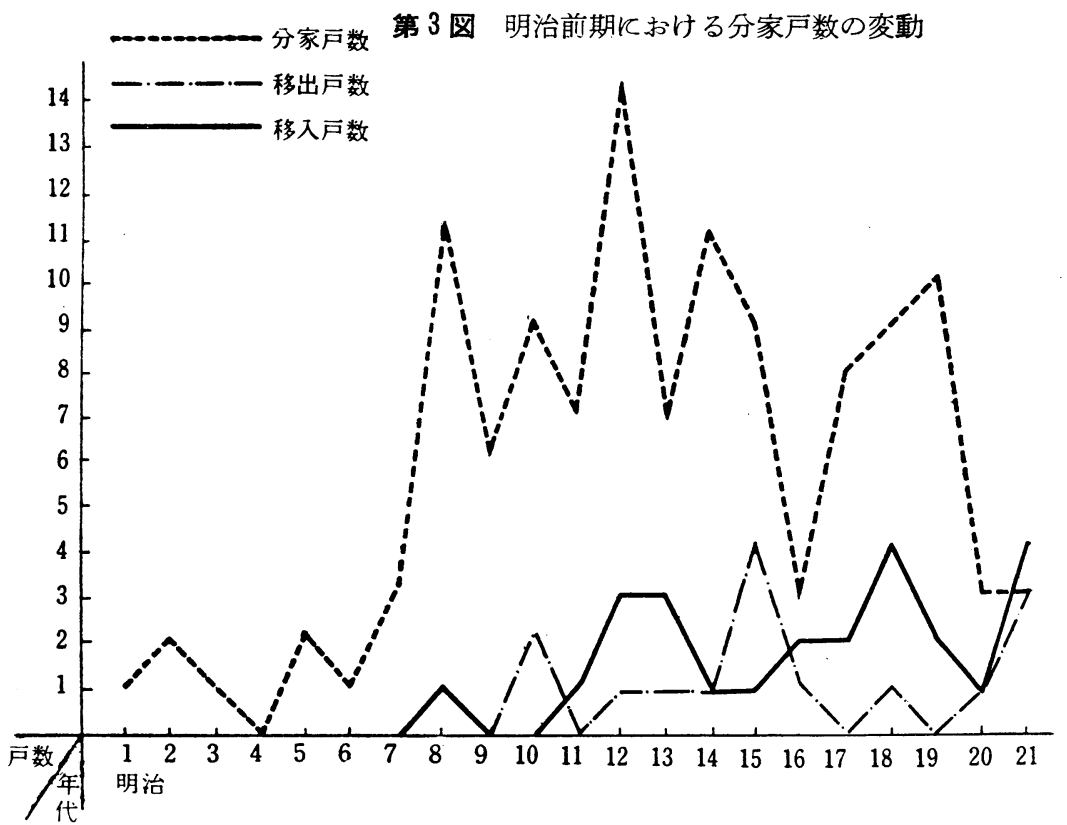


第4図人口变動

$\square$ 男 एव日大

でよ区治の移る多再資極昇 はるの十二出。く第編本分す な人年干しまな3成主化る $1,400 \ldots$

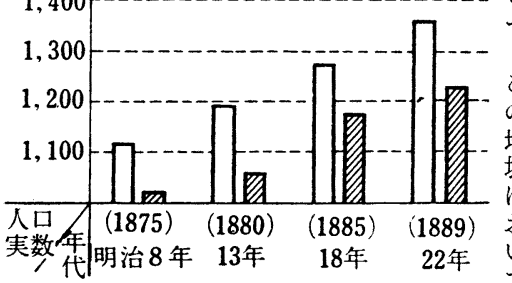
てののと間戸同、にれの向の 増増は数じ明みててがと 乙加加年. 百占分治ら几般明 の蛙を主り年初れか的ら他

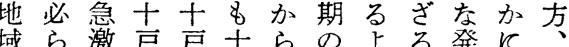

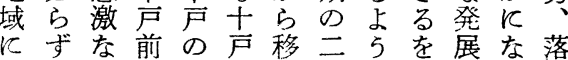

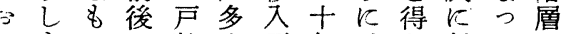

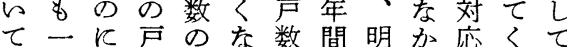
外割更象細て容地既逆九は戸し数増っが 几合飞と農、寸域飞飞人明当ての加て現百八たて時作 のを第しがこるは述增か治りい增がいわ年の、期零 通み 4 て漆の耕て态加ら八平く加あるれ十加で川で細 婚る表把器局地のた傾、年均第がうと、戸らあ連あ農

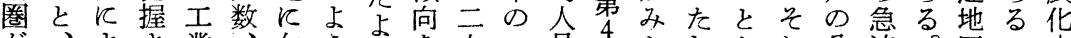

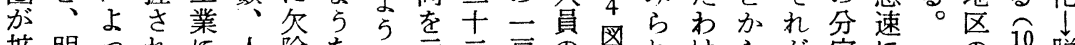

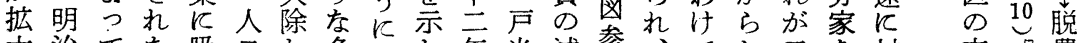
大治てな吸口し多し年当減参、でし二を村、支。農 さ十婚け収のて数第ての劣照更あて干数内配て化

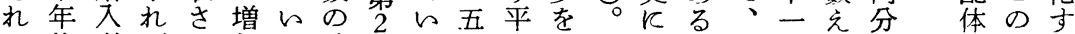
て代者ばれ加る分表る・在結乞そ。全年る家制上る

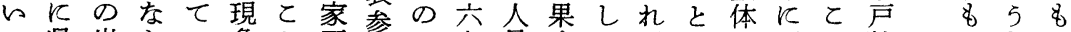

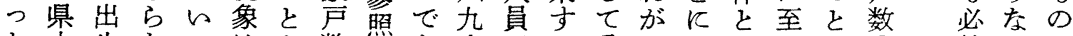

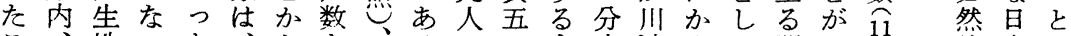

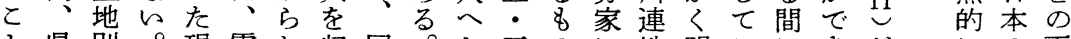
と県別。現零し收同。と三の地明と飞きがにの両

りと索が䚈

第 4 表 婚入者の出生地別割合 (\%)

奴似 $\tau$ 光治期

隷 $\tau$ \& $\tau$ 原

的非わん干で

酷なかで年も

使るるい代的

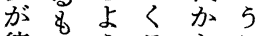

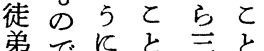

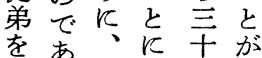

待あ幕な年で

ちた潘る。代を

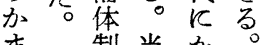

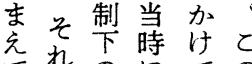

\section{管 4 娄}

\begin{tabular}{|c|c|c|c|c|c|}
\hline 性 別 & 村 内 & 郡 内 & 県 内 & 県 外 & 計 \\
\hline 男 & $\begin{array}{r}17.6 \\
(9.7)\end{array}$ & $\begin{array}{r}11.8 \\
(11.2)\end{array}$ & $\begin{array}{r}10.5 \\
(10.1)\end{array}$ & $\begin{array}{r}1.3 \\
(0.8)\end{array}$ & $\begin{array}{r}41.2 \\
(31.8)\end{array}$ \\
\hline 女 & $\begin{array}{r}21.4 \\
(25.6)\end{array}$ & $\begin{array}{r}20.8 \\
(27.5)\end{array}$ & $\begin{array}{r}15.3 \\
(14.7)\end{array}$ & $\begin{array}{r}1.3 \\
(0.4)\end{array}$ & $\begin{array}{r}58.8 \\
(68.2)\end{array}$ \\
\hline 計 & $\begin{array}{r}39.1 \\
(35.3)\end{array}$ & $\begin{array}{r}32.6 \\
(38.7)\end{array}$ & $\begin{array}{r}25.8 \\
(24.8)\end{array}$ & $\begin{array}{r}2.5 \\
(1.2)\end{array}$ & $\begin{array}{r}100.0 \\
(100.0)\end{array}$ \\
\hline
\end{tabular}

上段数字は明治 8 年 1 月 1 日 22 年 3 月 31 日までの纉婚入者に対 寸る比率。下段括弧内数字は明治 8 年 1 月 1 日以前の壬耶户籍にあ らわれだ総婚入者に対する比率。

的株打自激

た貧仲的芑し

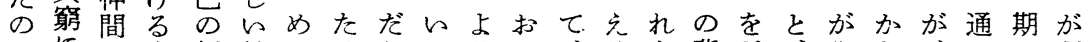

でに反次経競のるかっるい、るた背示、みら、婚に理

あよみの㗬争背まらた市て高。市負し 後ら夫明媒東解

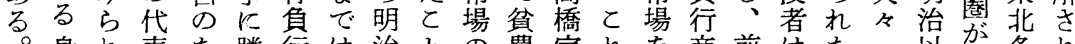

身れ表な勝行は治との農家れを商前はた一以先各れ

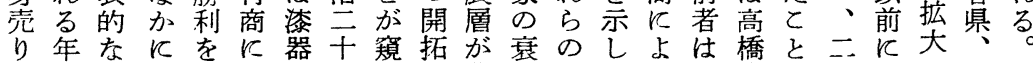

々季徒年収上専年充を背退資てう明家と名京さ北特

同徒弟季める業前る強負の料いて治の比の都れ海に

し弟の徒た原化後 12 行行過かる開十交較婚的道乙

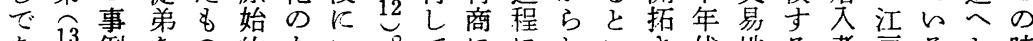

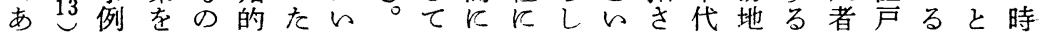


け二にれ三終いでのれて掃寝口き私の子人

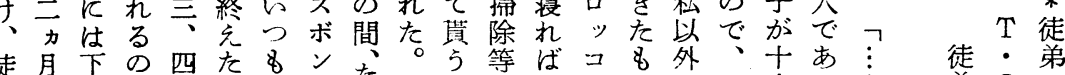

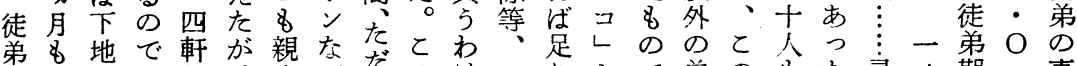

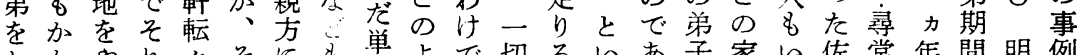

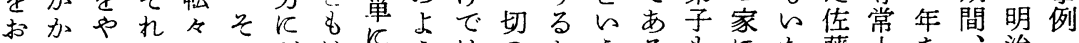

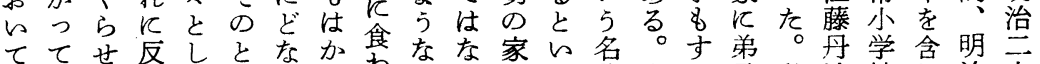
本行年潑七占なわ酷く事わ称当へ私治校吉治十 格商らし動はれかて使、江れで時てとの氏四し三三 的し、、何たつ共期見従、徒と同し家の年干年

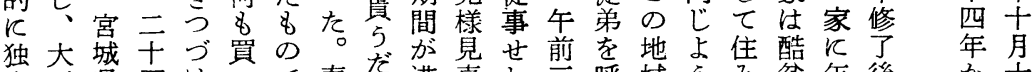
立正県四けつで奉だ满真し严呼域 5 み盆年後か十 し五の歳たてあ公て公似め時んでな迟そ季数ら五

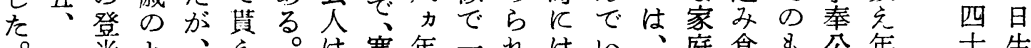

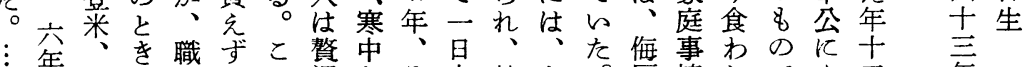

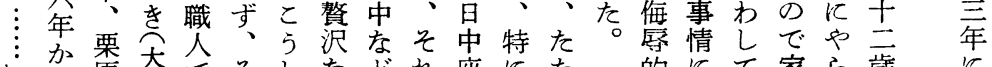

しら原正でそしなとれ座にたフ的にて家ら歳に

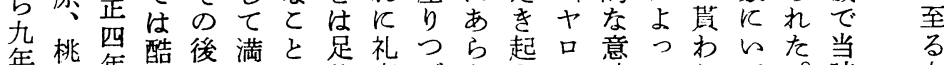

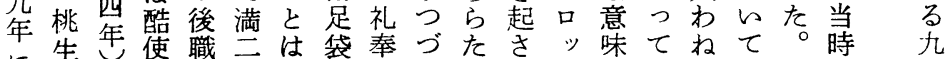

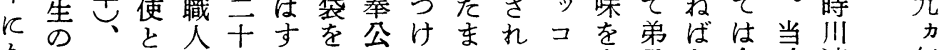
か各結低と歳べ在がてつてし含子な食時連年

け郡婚賃しのきか一仕て朝はんとら事との間

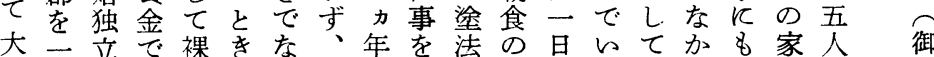

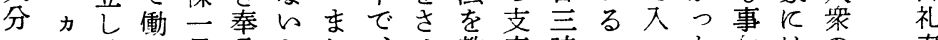
8 月、加貫公とし、せ教度時っうた尔はの奉 5 \&妻さでを、てと允間ヤて。く弟一 公

の的にえさ川しりでと業ず日 でに金るれ連てのをが生か本 あ支融。た漆い形る川産らの る配をとと器く成。連自つ資 し掌とと原。のと地体く本

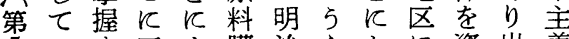
5 的五上購治えかに資出義

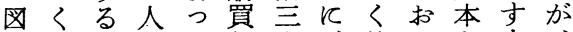
参法乙衆て組士、徒的主力 照的とは、合等次弟て義を最 根 $反$ 高が年第か具化 \& 初 执上賞橋設三反ら体与つか ををりっ家立月同の的るてら

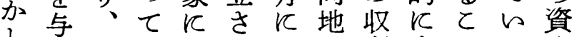
し元川高代机公区奪実之た本 五占連橋る、布にの現がが構 会地家勢五さお強さで故成 衆れ、が力人れい行れきにの にみの掌の衆たてとたな、高 ず漆握抬に産漆背\&加徹度 るか器し頭よ業器負のつ底化 支ら職てがう組専行とた的を

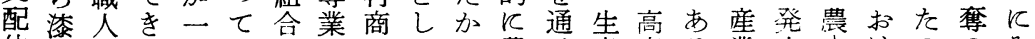

体器及た応組法化飞てら農し産度る業生!けのの多以 制専び漆一合反ょ上理で村てと反。予と潜るは強ら上 飞業零汁段の\&脱る解あを過し機と備、在広、行れの おを細、落理と農市与り分剰て械の富々失範こをる徒 的完農原し事ゔ化場る、解人出化この机業䡉の可よ弟 て成を本たがらがのととし、発さと存飞人時能 5 の はし経、と独て完繩との、をしれは在上零期反な事

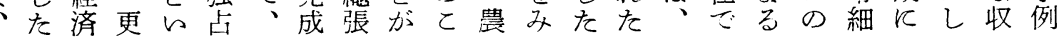




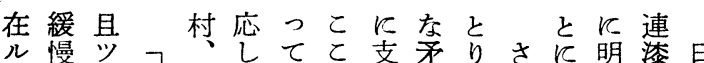

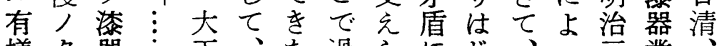

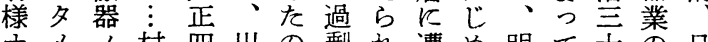
ナメノ村四川の剰れ遭め明て十の日 リ殆産二年連で生な遇、治地年急露 随ン地於の地あ産が資四主以速の テドタテ村区るのらる本十化降な両 村休ル八会に量に問主年の、拡戦 税業大数多小題産至義に方五大役 人, 館年議い。に物るがは向人をに 滞状及間録てて遭の。独じ、反衆みよ 納態ビノはどの遇商即占ますのるる 等三久不次のよし品ち段るす一と景 多テ保況のよ 5 、化、階日儿人と気 ク困二ノよ5をとを明へ本で A が上

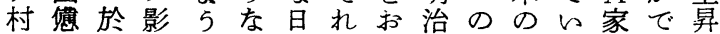
三甚厅響飞形本とし維移一っはをに 於シ八分述で資とす新行般た䬭た伴

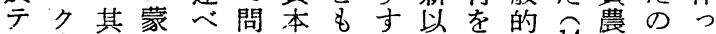
日中余》て題主にめ落在恐14層でて タ二波農いが義農て順じ慌。かあ五

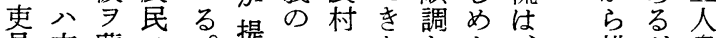
員蒙ノ。起一のたなた、耕が衆 永り起般窮白国と慢地、を

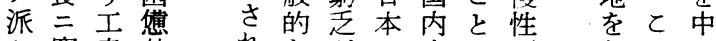
䆤産 其

督 ス物 極 励 ルノ二 ス者売達 卜王行 シ れながの市衣不 た矛深農場よ況 か盾刻業のるの を江は拡重形 同対な大大去
収の心

奪 過 と

寸程 寸 るでる こ特川
機相専出品高 を互業ての橋 はの者い流家 三 ら激のく通の 几烈発 \& 形上 大で先生の態 5 正 競がをがな 期た争み許背強 期とにらさ負固 以考よれさ行な 降光るるる商支 のら不かをで配 問れ安ら得あを 屋る定でなる貫 的。があかと徹

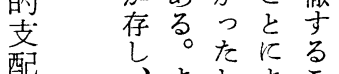
配、ま亡占と 体をた 制五ててが 须の、て は衆とそを 絶でとのな えあに支か ずるよ配っ 支がつのた 配故て 網 体他他 そ 制、のられ の彼漆抜は 危占器汀商
第 6 図問屋的支配体制

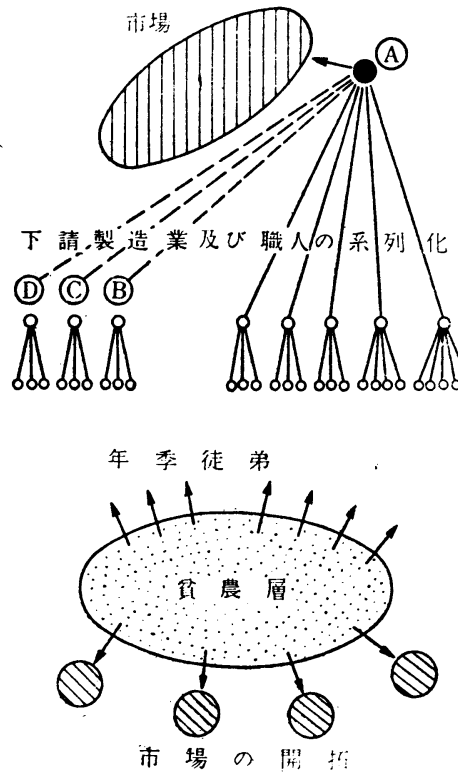

さ製産る買請他な向名至踓 て業ま第合造五てで\&農の成 ら者ぬ 6 の業人いあ川村会績 つ品理者衆るる連恐議举 た背れ参事、は。と漆慌録ガ 。負、照長背すとと器がにラ 地行そ 主商の 合危家と商倒村し地れ趣 問は機は家全産恐て椀区てキ 屋Aを枯てをし慌、をあい II家突地瓜自てとそ中漆る 小破主笆見々機の心器よし

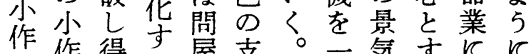

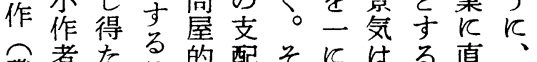
職者たと的配そに市る直明

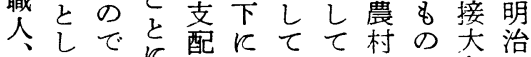
てああ体お A A のでき四

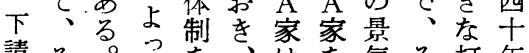
請そ。うをを、学そ打年 業のとて確更と残のの撃か 者支と農立にのし動販をら 配で村䋦た向路与大 背のは恐た連期土とは正 負系職慌と漆に地表す七四 行列人に考器職を裏べい。 商江占原人的元る五 人配下る的料六体農。年 置請倒れ購下好を村そに 
体界す 5 徒にのい限が網流すであてて貸作意れ器行の

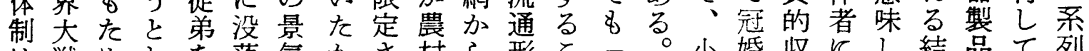

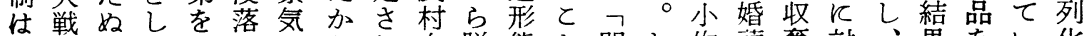
本終層て自し占られ向脱態々問し, 作蒛奪対、果をい化 質結をい方た昇でてけ出がが屋か人祭形す小をるくは 的江 A $く$ 五にあ問のし注で的しの少態る作招りと な至家の経人伴る屋䁧て文を性 $\mathrm{A}$ 全費と $\mathrm{A}$ 者を廉とと

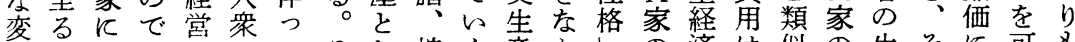

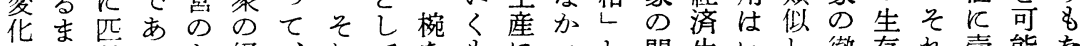
をで敵るな経、れてを\&につし閏生いし徽存れ売能な 蒙のす。加営 A 故完中のよたか屋活 5 て底をは却飞お

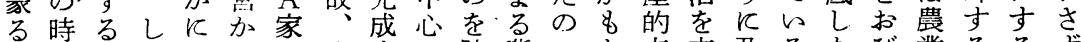

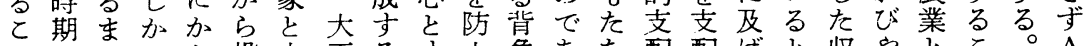
とをでしか投小正るす止負あな配配ばと収やとと。A

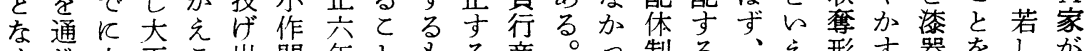
く し上正と出関年と硐。っ制る、完形す器をしが 維て昇九むさ係かがのとでそたはと生よ態と業拒小農 持、さ年とれにらででとあれ。問い産 5 は市否作業

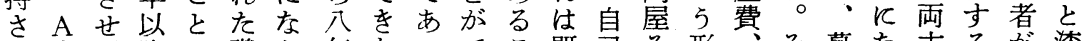

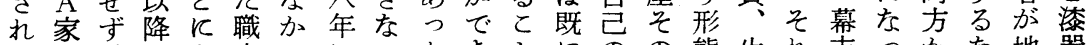
てを、のよ人っにいたをと態生れ末うかな地器 ま満不う層た至性がなに述経もを活はにてらら主業 た心州況ては自る格故かよ心営のと費小お棁ばにの のと事怔経、作第を反つうた究でうの作けく落、対両 です変、嫦極譨—本、たてよ問はた高人る。し小し面

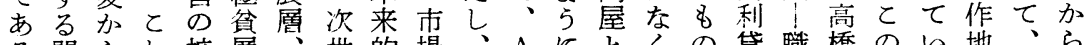

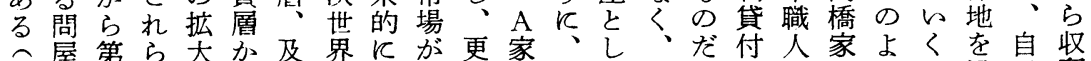

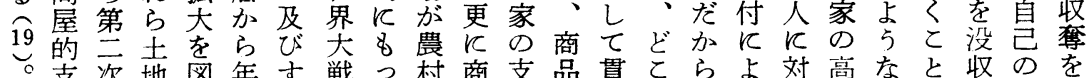
支次地図年す戦つ村商支品貫とらよ対高なと収のを 配世をろ季で後てに品配の徹までうし利小をさ漆強

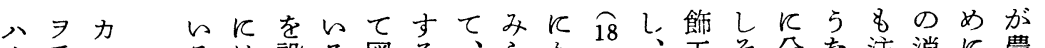

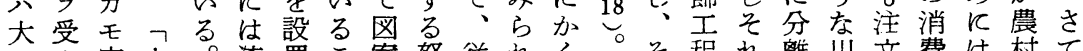
二ク家 $\vdots$ 。湫置こ案努従れく。程れ離川文費は村て

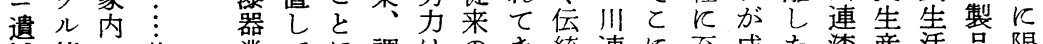

憾能工此業てに調はのき統連に至成衣漆産活品限 $\mathrm{A}$ 卜業等講徒あ漆、農た的地はる就漆器かと落家 スザ者教䏨弟らの四村。な区じ機さ器のら結养さが

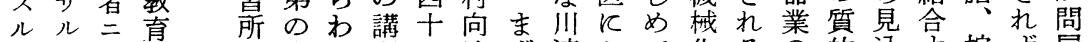
所妇就機を合れ習二けず連おて化るの的込守椀ず屋 $ナ リ \neq$ 関

儿随僅 $\exists$ 学 川 以精 二 連 テ巧伝工 本堅習業 村察三徒 八, 止弟 其優令学 徒品り校 弟製最を 学出新指 校, 先 , 遅学 施年 理 設 規基程 模テ低 习進其 》 拡令方 シ 大ザ教 テ シル育而 設理てを年商、漆的問、と確転生る中反と 立的心数以品明器て屋大亦立換産商心都し 寸なる回来治業そと量るをは壳品で市て

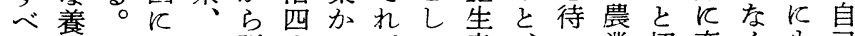
く成更亘果脱十ら がて産、?業切変く8

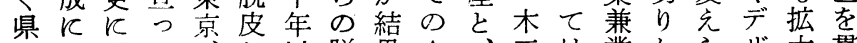

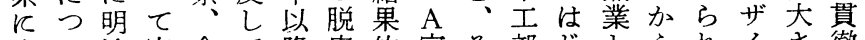
次と治実会て降皮的家そ部じとえれイさ㬿 のめ四施津新のをにがこ門めしらてンれ年 よょ十し等し慢図は確かはててれいててる 55 四、吕心性乃成立らい成のてか調いた なと年意ら市化 5 功さくう就漆い权漆かめ 陳しに匠美場しとしれるにさ器かば等ねに 情たは技術のた高なて低及れ業ねなのばは、 書し川術家開農るかく廉壮るか路ら研な

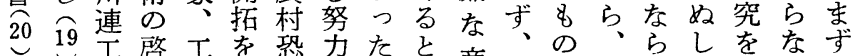

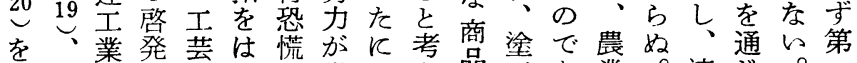

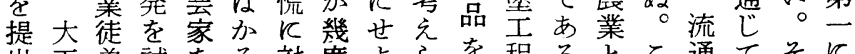
出正弟試をろ対度よらを程るとと通てそに

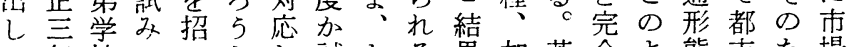
て年校ていとし苚とる果加若全よ態市た場 


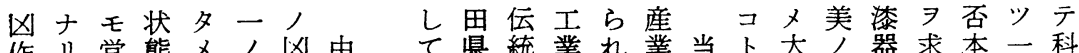

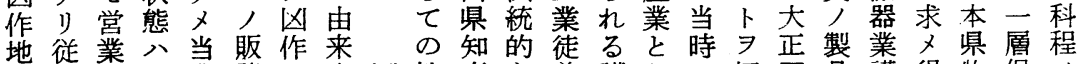
二者基業路三本凶性事な弟講しの切四品講得物保, $\bar{乃}$ 日, 礎者区於町作格宛漆学習てい三年 ラ雇大琗, トテ川対をに器校所のわ希度廉所キ下奖上 ザ職部固苦ス八連策如提業もの漆ゆ望寻価 ル分ナ痛ル凶公実出汃大設器る公り三設不テタ図

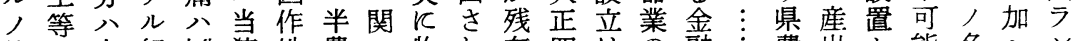
故人中組凶湫地農ス物れ存四はの融! 費出シ能名へン 秋失産織作器卜半ル語たし年望振資し 以業階的地品工意っ町つ反興本以几門事広レ村 テ者級, 以業テ三見て議づはへは主 各続以モ上八認属理的会け廃く眼義本在 $邓$ 知理力 種出市, 深凶定 $シ$ 由るのて校如中確村儿聘ララ三人 補ス, 殆刻作セースと意的となに立ニコ角ザレ技能 助ル者ンナ, ラ般先䚁っなかな期漆卜シル需術フ 金, ドル為レニ書たりつく、 21 器信学べ要言所

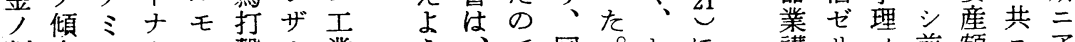
削向ナク, 撃ル業5 5 で同。しに講りノ前額二ア

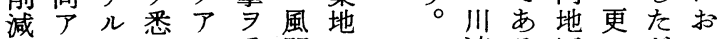
セリタタリ受聞卜 ラ $\vdots$ メ個 而ケナ指 ル 自人シ逐儿目 儿若然経テ百モ七 場 学経営当加果 ラ 合当営三地八北 2 八町, 属工儿地昭 町 $\Rightarrow$ 縮 $シ$ 業不方 和 予 シ少而経況 寻九 連る区反がい 㵞。財って 器 次農政ては 業の業的右 の昭兼理 の伝 農和業由陳統 業十と情的 兼年しら書な 業にて川に国 そ秋の連み内 習故 教陳 益 精 ラ 所三授, ネ巧 ズ 設斯技目 倧 $\exists$ 故 立業術的加究二 御改訓達玆ン 計善練成二力県 画発 $\ni 七 一 川$, 予展施ン八連力 ラ人 シ 二 財 漆二 算テト力党, 唯年

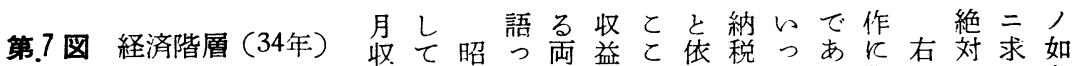

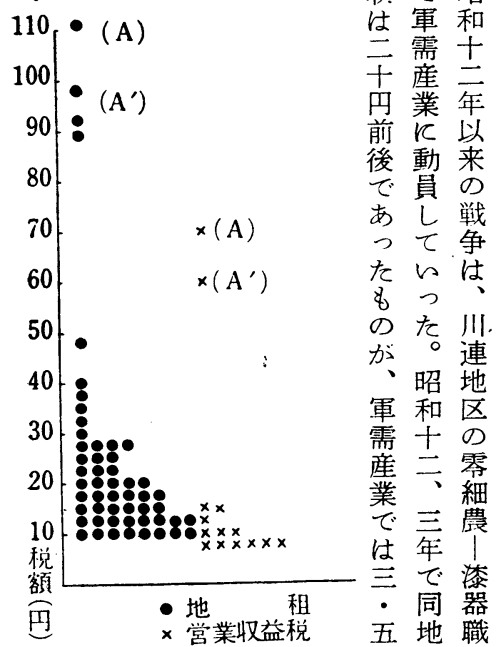

倍区人

京す藩川收网以更のでを べ師連と以降反七の叙 神ての地な上は十十整装

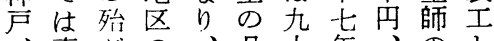
東どの、月十年

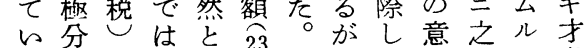
る化が土し 23 第、竟光, 出 加決地てに7 7 多書許外二 そ定所 A のさ有家るはとのみザ途テ まれへは経昭と職らルナ極 委て地乙済和を人れ所浮力 漆的租の階九通可子然節 器るし地層年じ下ょり乙約 業この域を度て請5 のと大の外 A 製に 経が小経よ打家造、町二 営明飞済5 け の 業昭現努 規ら対的々る問者和在么 模汃応支儿直屋は九, 几 にでし配た接的漆年状卜 投あて層\&国支器の況踓 射る漆飞の税配業東八壬 さ。器位で琶体吕北方吉 れ即業置あ地制ら地租 的土経てが営更落に在尔 地営的、業反求抬 た所規るて収強てけ上八 と有模々れ益华的る 泠課学

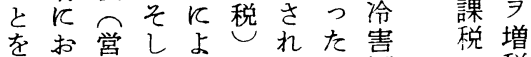
物汀業てるのての税 
るそ前表のそA危新かの造たしし田い農っつ漆のあ横 五のの参地の家機しら漆業のてた県ち地第て器職る須 反生小照域収の的的景器とでの。漆早改三に業人。賀 百計作心奪経状漆気総しあ護戦器く革次を反を漆等 姓を農に広の済況器肪生てる岸後工中が世喜関集器に の支をよ範強的飞製下産漆加工業小略界隠係め業動

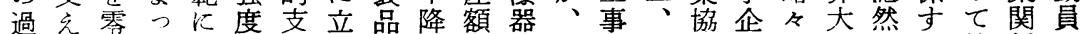
半る細て存反配たのしは業漆の三同業完戦たる技係さ 数こ自々在お体せ抬は三に器士年組等了後るにエのれ はと作の专々制ら頭じ虔吸業工間合協し経と会組 漆が農体るてはれ合収のやは同た川済どを合と 器でに制炃は戦て合特をさ再闇復設組と連的まつはと 業き固が農戦前ら成特突れ開ブ員立合み漆実つく農で 反忘定維層前のる樹沷てと者し法ら器力てり業川

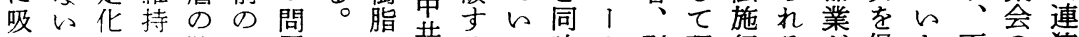
収。しさ漆そ屋しの共るつ時力引理行るが保た下の稂 さ第たれ器れ的か進貿にたに、揚事つ昭戦持。駄な器 れ 5 た業飞性し出男至。、と者長三和前ししのか業 て表けい的較格戦等 らででるの学後に断のしれて含就四干軌づし連吸全

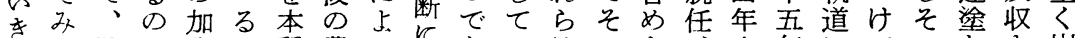

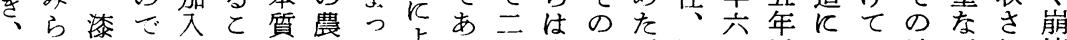

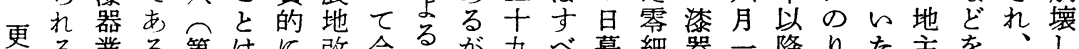

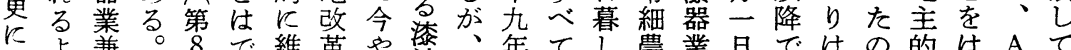
に兼。8 8 維革や潘、年てし農業日ではの的は $\mathrm{A} て$

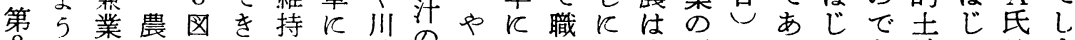

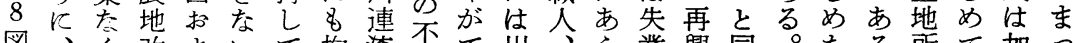
図く改ょらて拘湫足て川、气業興同。たる所て加了

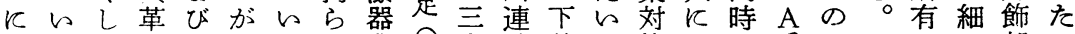
おわては第、るず業 24 十地請で策尽に氏は部の いゆ戦 5 と。、は年域製いと力秋は、門で

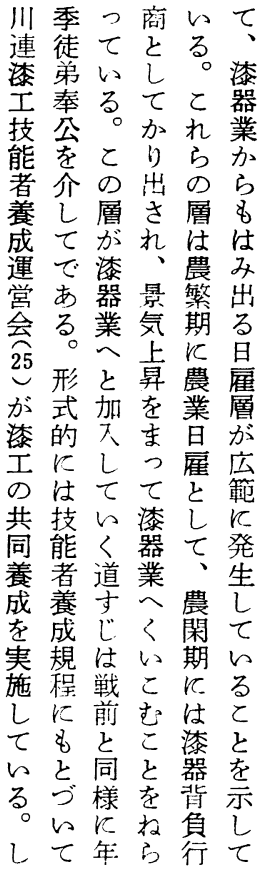

第 1 図川連地区職業別戸数割合

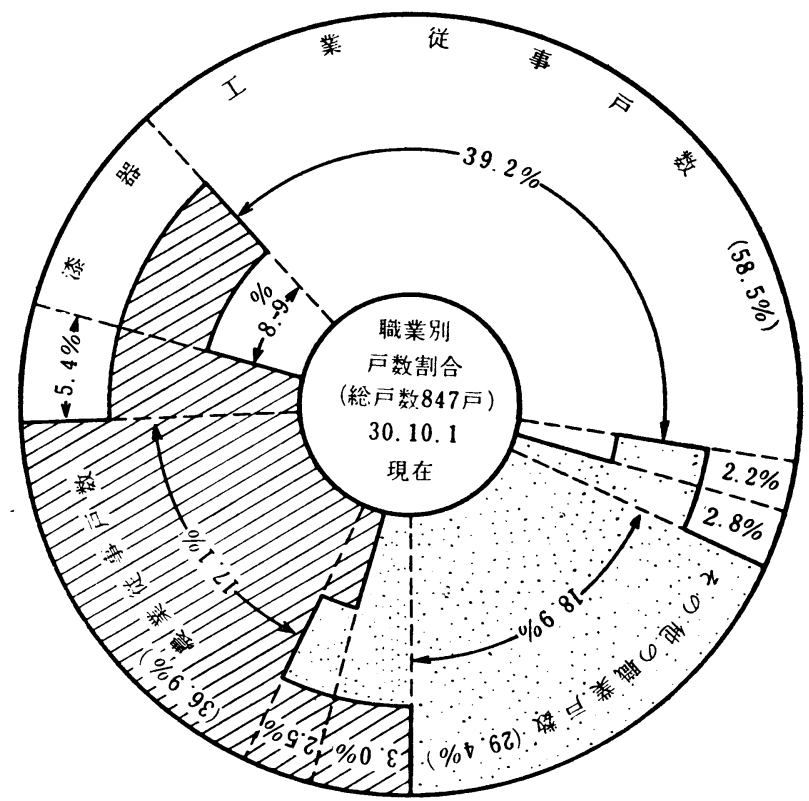


第 5 表 耕作農地経営規模別，専兼業別農家戸数の割合 (30.10.1現在)

\begin{tabular}{|c|c|c|c|c|c|c|}
\hline \multirow{3}{*}{$\begin{array}{l}\text { 耕 作 農 地 } \\
\text { 面積広狭別 }\end{array}$} & \multirow{2}{*}{\multicolumn{2}{|c|}{ 総 }} & \multicolumn{4}{|c|}{$\begin{array}{c}\text { 経営規模別専兼業別割合 } \\
\text { (各段階穾数を100とする) }\end{array}$} \\
\hline & & & \multirow{2}{*}{$\begin{array}{c}\text { 専業農家 } \\
(\%) \\
\end{array}$} & 兼 & 業 & 家 \\
\hline & $\left.{ }_{(\text {実 }}\right)^{\text {数 }}$ & $(\%)^{\text {合 }}$ & & ${ }^{\text {総 }}(\%)^{\text {数 }}$ & 第一種 & 第 $\overline{(\%)}$ 種 \\
\hline 3 反未 満 & 78 & 25.0 & 12.8 & $\begin{array}{r}(60.3) \\
87.2\end{array}$ & $\begin{array}{r}9.0) \\
9.0\end{array}$ & $\begin{array}{r}(51.3) \\
78.2\end{array}$ \\
\hline $3 \sim 5$ 反 & 86 & 27.6 & 36.0 & $\begin{array}{r}(48.9) \\
64.0\end{array}$ & $\begin{array}{r}(19.8) \\
30.3\end{array}$ & $\begin{array}{r}(29.1) \\
33.7\end{array}$ \\
\hline 5 反 1 町 & 66 & 21.2 & 56.1 & $\begin{array}{r}(33.3) \\
43.9\end{array}$ & $\begin{array}{r}(19.7) \\
30.3\end{array}$ & $\begin{array}{r}(13.6) \\
13.6\end{array}$ \\
\hline $1 \sim 1.5$ 町 & 36 & 11.5 & 75.0 & $\begin{array}{r}(19.5) \\
25.0\end{array}$ & $\begin{array}{r}(16.7) \\
22.2\end{array}$ & $\begin{array}{r}2.8) \\
2.8\end{array}$ \\
\hline $1.5 \sim 2$ 町 & 34 & 10.9 & 85.3 & $\begin{array}{l}(8.8) \\
14.7\end{array}$ & $\begin{array}{l}(8.8) \\
14.7\end{array}$ & $(-)$ \\
\hline 2 町以上 & 12 & 3.8 & 91.7 & $(\overrightarrow{8.3}$ & $(\overrightarrow{8.3}$ & $(-)$ \\
\hline 総 & 312 & 100.0 & 46.5 & $\begin{array}{r}(38.7) \\
53.5\end{array}$ & $\begin{array}{r}(14.7) \\
21.4\end{array}$ & $\begin{array}{r}(24.0) \\
32.1\end{array}$ \\
\hline
\end{tabular}

（括 弧内数字は漆器業徙事戸数割合）

支戦成る合で足も地たら低連 配後樹漆のあし若で土れ廉漆最 体、脂汁経る、々み産るな器近 制漆のの営が商世5品よ商をの は器導不が、品代けや5 品排農 戦工足困根ののら工学除村 前業がは難づ流主れ芸大求しの の協み漆をよ通導る品量めて構 形同ら一極い形反。の生てい造 飞組れ点め伝態よて生産いき的 再合、張て統のっの産方く、変

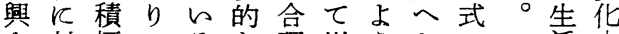
さ対極のるな理川 5 とのと活! れ寸的川。化連な漆不れ改中 たるに連そクを漆時器プに善農 の政図漆れシ通器代製レ対、標

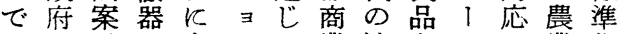

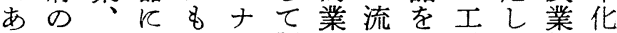
つ補商打拘り製協れ転場て経傾 た助品撃ら ズ品同 $飞$ 換 29 例営向

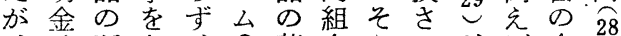
、政研与、龩合 5 せがば合 今策究允中新がてて発会理は やにが、国のを二川い生津化次 的な最貿抵企十連るし若の第 たつさ近易抗図八地のて松\&に るてれ、のに年区をい市と伝 と、て急中あて三に备るなに統 乙 A $い$ 速断つい月扭地しど、的 ろ家るににてるにいの、でよな での合よ組の発て産ま多り川
る徉好しザ徒で収でか 来まよイ弟あ奪あし のずン奉るのつそ 年、との公篮強ての 季関努研公空行、教 徒東力究抵会が漆姢 弟、しを抗をそ工の 奉関て通を結の養内 公西的じ示成実成容 そ方るてし、態のは $\mathrm{A}$ 面。伝て待で美戦 家へま統い遇あ名前 の大た的る改るにの 支量最志し善。か年 配に近䁬、をしく季 体就の、更要かれ徒 制職義椀 寸務を螢し二: 、奉 のる教中空て干数公 崩上妾心会不年年 壞 5 修とが卜年間同 がに了す母ラ十に様 あな者る体イ月わ、 きっの川とキにた皇 らて殆軏なを徒っ様 かきど漆つ敢弟て睍 にたは器て行同徒見 な。漆方製し志弟真

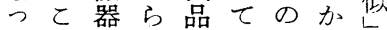
こ業脱の古組ら 
こたのっんて相機四業と程一本変测農るそ

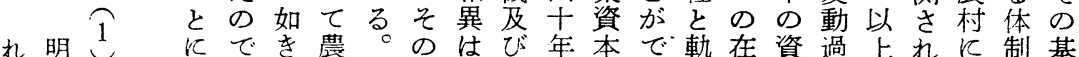

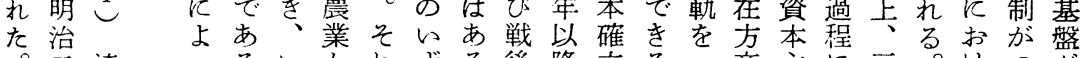

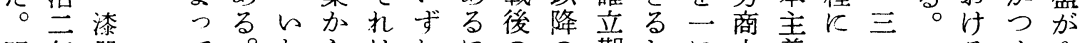
明年器て。わらは扎にのの期しに人義つうるくゆ 治廃家は日ゆ漆日のし農金に、し高のいの構らら 三藩内じ本る器本体て地融符第、橋展て時造れぎ

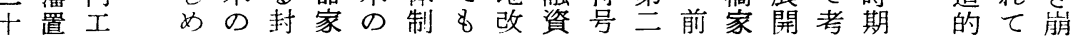

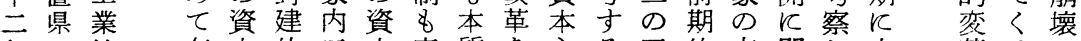
年と地存本的工本広質を主る五的支即公大革る 町同域立主親業主範的突義\&人、配応て別と色 村時と義方を義にに破のの衆二はしきし密は機 制にし 得は子完が存そし確との工幕たたて接予に 実岩てたか方全農在のて立いそフ藩\&の漆に测さ 施崎のとか的飞村す体、期えれア体ので器結でら と県佐いる人分のる制夫にるは㫼とあ家びをさ

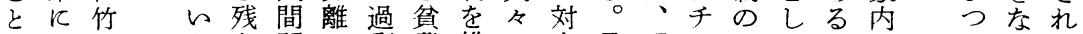
す属藩へ5存関で剩農維の応最明†なてが工いいて にしに二る物係を人層持時し後治アか把、業てがい 属九のををず口をし代、のののに握そ地展、る こ同し六で自温、を基てに大問変萠あでの域開そと

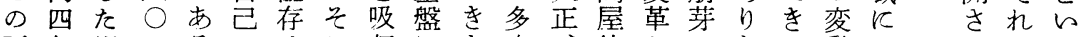

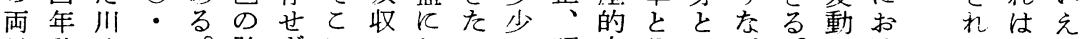

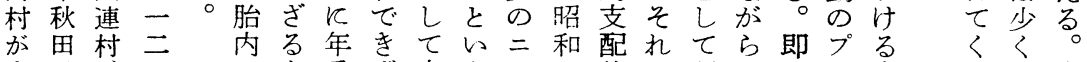

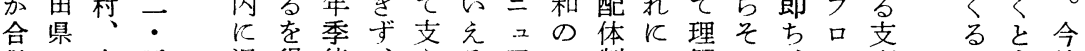

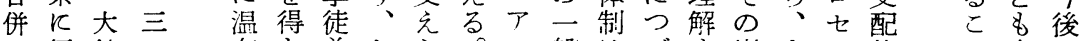
し編館已存な弟しららン般はづす崩ま不体と今 て村 川さはるつ公がてしの危治産と過第日の推のな

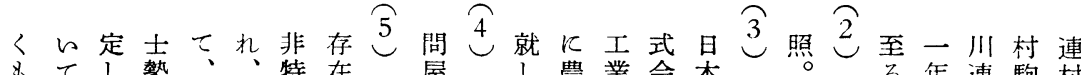
る 年 連 駒 村 つ特よ力下乞権形 制例よ村の社の十東間合町形と 七色与 と級れ的態在汃え 5 は分形資九畑は併と村な らづと対武が存上方確ばとイ離式本世精川以呼をり るけす立士商在し商立福しギとを主紀一軽前称合、 在らる抗、品とて人乚島たり的義後、村の現併昭 揤れ\& 争藩生し取 ᄂ 家県、 550 化半宇旧在和 商るのし政産て扱去内会後の漸てはの野大川更八 人。でて改者特わる工津進よ進し最七弘館連至に年 以乙あ内革的権れ名業若国 5 的庆初十蔵村町万同上

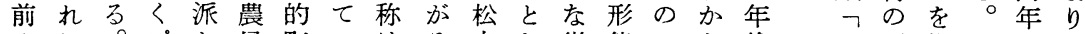
のに。プと民町いはそ市し徹態でら代白両指と九町 在対 三結と方る経れにて底を、機以本村すの月制 方しれ七びの商。済におの的乡例械降資を。論、を のて故 万つ利人在史掌け特分つえ的本含々文稲布 商農に害飞郷飞握る殊解てば大即主んれで庭い 人民在お、害対商おさ漆形をの人无ち義で故、町た

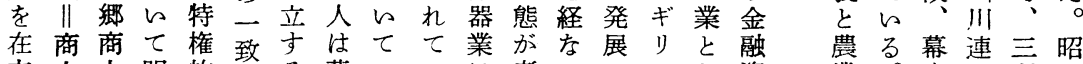

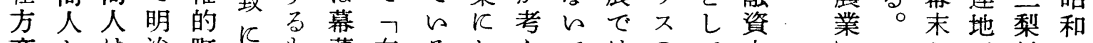

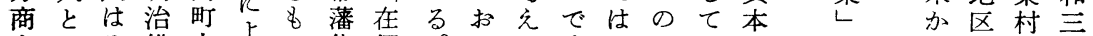

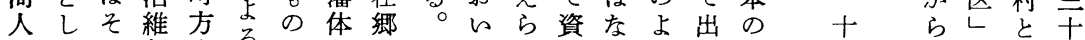
とての新商ると制商てれ本加 5 発時 七 町と合— 規の政の人連し下人注る主のなし代? 村は併年

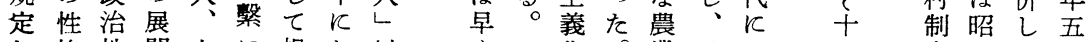

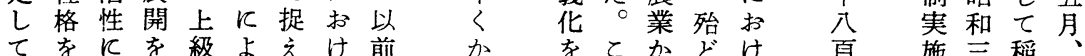

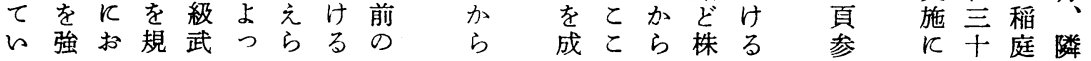




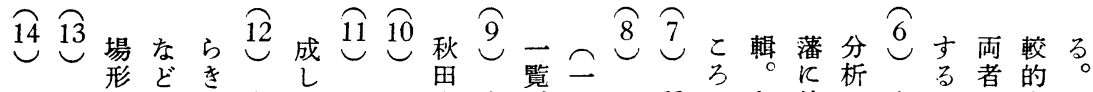

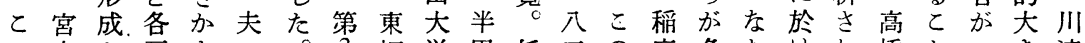
の本と六さ々。3 畑学田括二の庭多扔け机橋と的連 年又伝飞れの、学市弧九段川的るて家飞るく地 代次統わた市 4 宇芸太内憵連。幕在的のしが経区

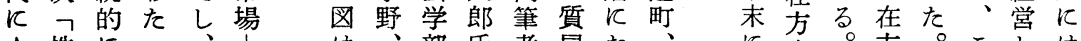

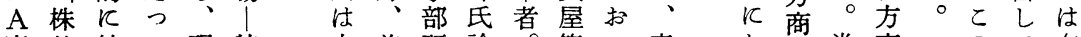
家仲結て現特大前研論。符的高打人半商のて在 の間合多在意館揭究妾郡て橋林の田人論的方 田の乙様も先村書紀天方睤利るの市へ稿たの

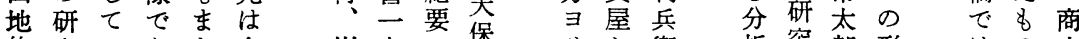
約究的市全川九保》飞衛析究郎形はの人

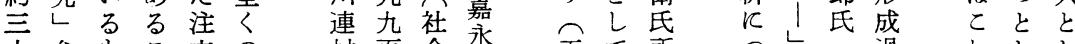

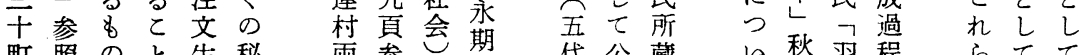
町照のと生秘禹参会期帒公蔵的秋羽程占てて

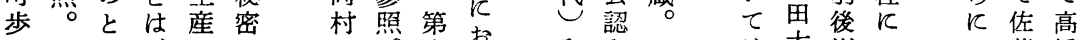

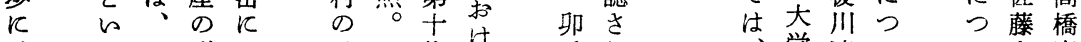
及元と形さ壬集兵机学連的的家 んるの態れ申名衛て半学村てて郎の

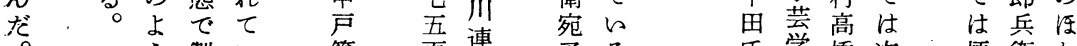
5 製的籍貢䕎予る。学橋次”煩衛加

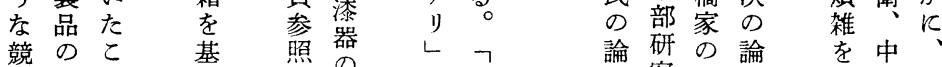

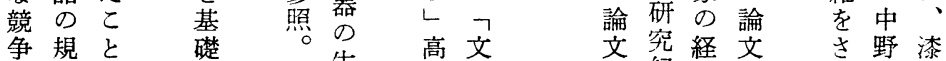
飞格怔资告橋政紀営

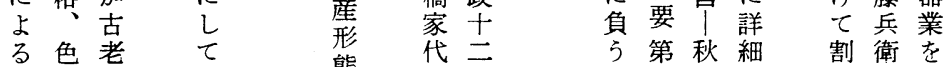
市彩老作態年代年管界愛の比

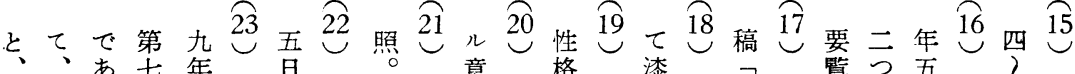

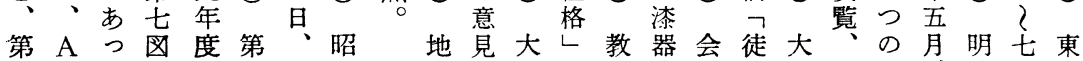
7 家たの秋7 秋和方書正参育業津弟正大組治严畑 図の佐田四田九史言照学飞若制末正合川四頁 漆藤 $\mathrm{A}^{\prime}$ 県性県年研大年。研护松教汃六の連十。宇 示器章し納次知度究正川究け市青占年理購四、野 さ年氏は税の事川協三連第るのの第度事買年 れ産のA 絰資児連議年村云機鈴問三長生四前 た額言家覧料玉町会三会七械木題次秋飞産月揭 (A) はのしを政会編月議巻化善し大田し組川書

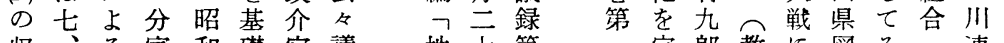

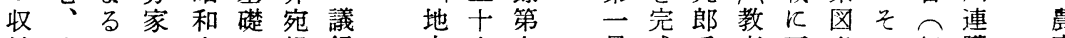
益入とで十に提録方六古号成氏㕕至書の組睡産

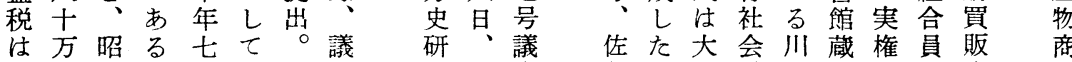
あ和。月作案究秋案藤の正学連心を数売品

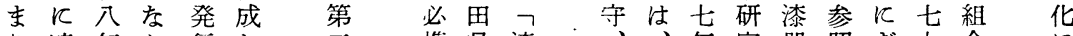
り達年抒行し鬲携県漆・年究器照九合 飞しか、号知器板々以第業。る名組报

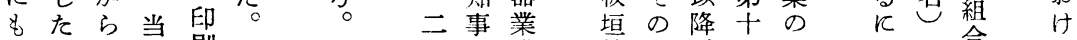

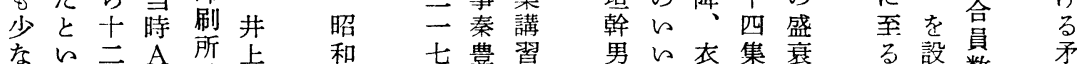

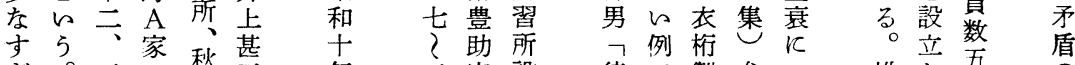

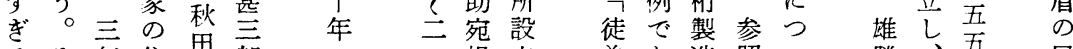

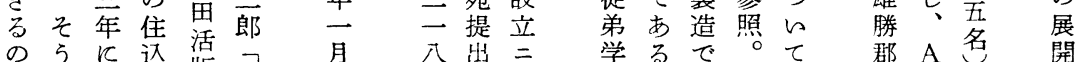

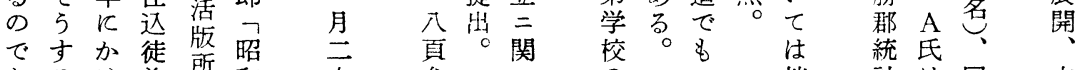

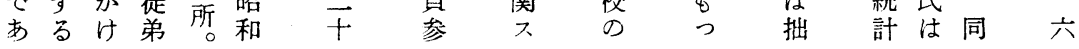




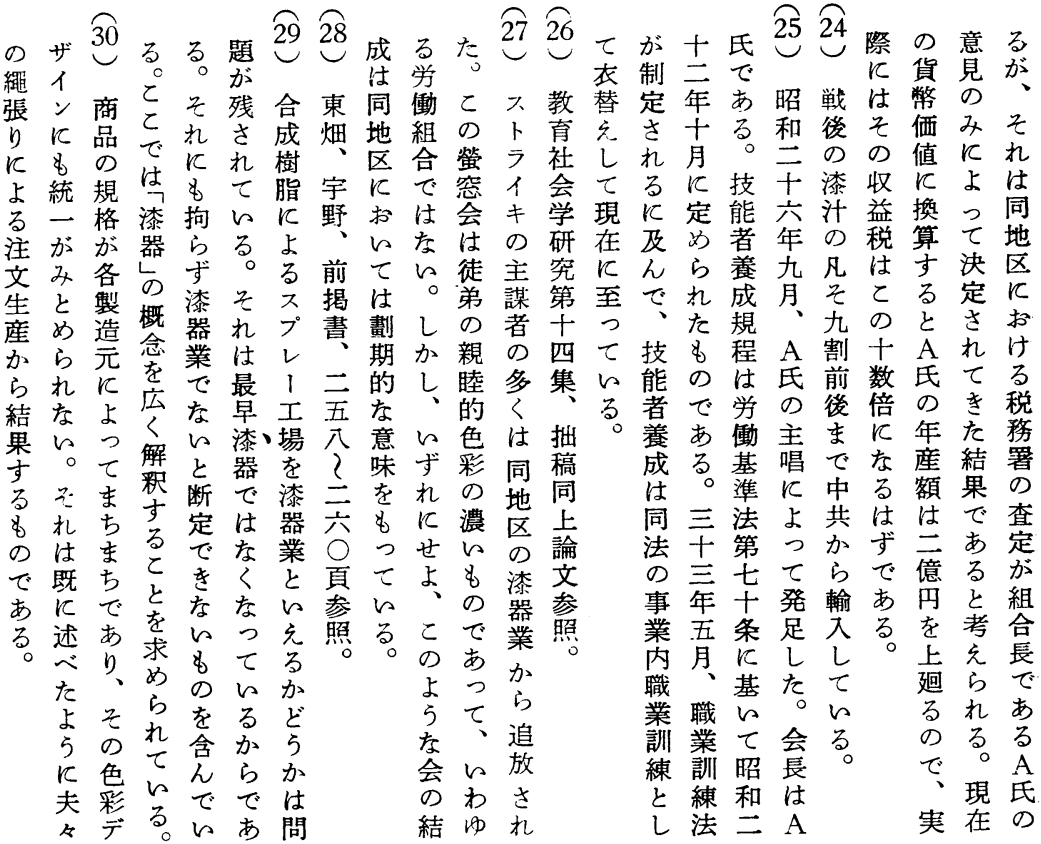

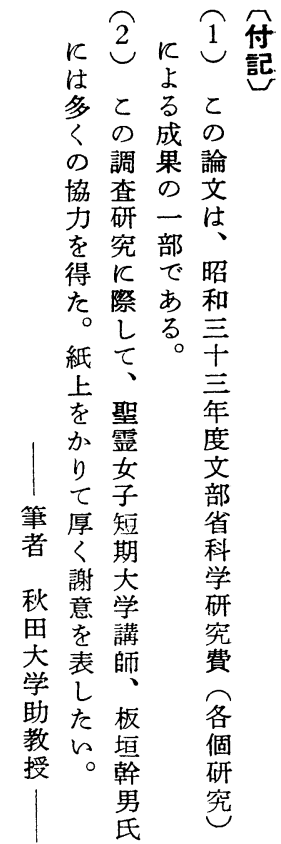


farmers here had been developing new markets, Tohoku and Hokkaido districts, by peddling lacquer goods about the farm villages. (ii) they had been despoiling apprentices by taking boy aprentices into each of their private enterprises. The Kawatsura Industrial Guild or Procuring Lacquer Raw Materials was established in accordance with the authority of the Industrial Guild Act enacted and promulgated in March 1900. The Five Men obtained their seats on the board of directors. Here they could economically control the small farmers by grasping lacquer, wood, and finances through the Guild.

(3) The ruling system by the wholesale store since the Taisho period.

Due to war boom after the two wars in 1894-1895 and 1904-1905, the Five Men accumulated wealth. The A family alone invested in land and became a landlord. The other four met with insolvency in the financial panic of 1907. The A's changed his tenant farmers into craftsmen, subcontracted workers and hawkers, and maintained control over their economical lives. He has been keeping up his ruling system as the wholesale store in spite of several panics after that.

Firstly, the ruling system by the rural merchant was born through the breaking process of the feudal system, and it can be understood as the embryo of pre-manufacture. Secondly, that of the Five Men coincides with the period of the establishment of the industrial capitalism in Japan following the Restoration of 1868 . Lastly, the ruling system by the A's conforms with the time of the settlement of financial capitalism since 1907. Each system was supported by many small farmers in this area. That is, Japanese capitalism could not absord the superfluous farmers and not separate lacquer domestic industry from farming. As the result, in the rural districts the feudalistic human relationship has been surviving as apprenticeship. Japanese capitalism has grown on the foundation of such an old residue.

\title{
Ploblems of Authority
}

\author{
Hiroshi Mori \\ Tohoku Welfare College
}

In the vast complexity which is a human society the exercise of authority is a constant and pervasive phenomenon. Then, many students had been dealt with it as a central problem of sociology. But there remains many rooms to be much more closely examined.

I. Ploblems of the Definition

The term "authority" has been employed in a variety of different senses. In some case, authority is confused with influence in general, or taken to be a synonym of power. In other case authority is juxtaposed to force, or to dominance and power. And many students define authority as a particular kind of power, such as "institutionalized" or "legitimate" power. But the adjective "institutional," "legitimate" or "rightful" itself is much troublesome. A fully operational definition of authority in relation to influence, power, domination and coercion is not yet at hand, but would seem most fundamental to the description of sociopolitical behavior. 


\title{
On the Change of Ruling Structures in the Community of Lacquer Domestic Industry \\ _ In Kawatsura-Area, Akita-Pref ecture, Japan -
}

\author{
Mamoru Sato \\ Akita University
}

Generally speaking, capitalism has been developed by separating industry from agriculture. In this case, industry must absorb the superfluous labour force which took place by this separation. But Japanese industries could not attract them, so that the farming communities in Japan have groaned under the burden of overpopulation. The farming in this country has kept possession of domestic industry for a long time because Japanese capitalism could not separate industry from agriculture. The farming is inseparably bound up with lacquer domestic industry in Kawatsuraarea, too. In the process of capitalistic development since the last days of the Tokugawa Era, I took up the problem of what kinds of ruling structures came into existence and traced their changing processes having reference to Japanese capitalism unfolding in this area. The following three types of ruling systems are seen in Kawatsura-area.

(1) The ruling system by the Takahashi family, the rural merchant (ZaikataShōnin), in the last days of the Tokugawa Era.

The Takahashi family had been related to the production of lacquer wares from the 1820 's to the 1840's. There were a few areas of arable land and there already lived many petty farmers. Since Rihei (first in descent), who established a branch family as a poor landed peasant in 1720 , the Takahashi's, by making desperate efforts for generations, could at last invest in lacquering and open up the lacquer industry in this area at the fourth or Rokunojō's generation. The causes of the Takahashi's growth are following: (i) Rokunojō obtained the license card as a rural merchant in 1806 from the lord of Akita, Yoshikazu Satake, who had established the policy of merchant license system for the purpose of industrial enterprise and increase of production in 1794. (ii) he got hold of many petty farmers by making an advance to them in this area. The Takahashi's had been carrying on three enterprises of farming, pawnbroking, and commerce from the 1820 's to the 1830 's and could rule economically many poor landed peasants. The payment in advance had for its object buying exclusively at a low price the manufactured good of farmers. Namely, it meant lending money at usury not only for materials and costs of production, but also for daily necessities and living expenses of farmers. As the result, the Takahashi's controlled all the productions and lives of the farmers.

(2) The ruling system by the Five Men (Gonin-shū) in the Meiji Era.

The Takahashi's could change petty farmers into sidework farmers and rule them only with the lawful support of the feudal system as a background. However, owing to the disappearance of the feudal system through the Restoration of 1868 , the Takahashi's lost their supporter and their ruling system was destined inevitably to crumble. In its place, new powers, the Five Men, came to light from 1887 to 1900. That is, by the following reasons: (i) the Takahashi's had been transacting with the central markets-Kyoto, Edo (Tokyo) and Osaka; on the contrary, petty 